\title{
使用済み自動車に着目した日本からの資源流出*
}

\author{
布 施 正 暁1～中 島 謙 $2^{2}$ 八木田浩史 ${ }^{3}$ \\ 1産業技術総合研究所安全科学研究部門 \\ 2 国立環境研究所循環型社会・廃棄物研究センター \\ ${ }^{3}$ 日本工業大学工学部
}

J. Japan Inst. Metals, Vol. 72, No. 8 (2008), pp. 557-564

C) 2008 The Japan Institute of Metals

\section{Outflow of Resources from Japan Focusing on End-of-Life Vehicles}

\author{
Masaaki Fuse ${ }^{1}$, Kenichi Nakajima ${ }^{2}$ and Hiroshi Yagita ${ }^{3}$ \\ ${ }^{1}$ Research Institute of Science for Safety and Sustainability, National Institute of Advanced Industrial Science and Technology (AIST), \\ Tsukuba 305-8569 \\ ${ }^{2}$ Research Center for Material Cycles and Waste Management, National Institute for Environmental Studies (NIES), \\ Tsukuba 305-8506 \\ ${ }^{3}$ Faculty of Engineering, Nippon Institute of Technology, Minamisaitama-gun Saitama 345-8501
}

\begin{abstract}
In order to examine the risk to resource security in Japan, this paper quantifies the outflow of base metals (iron, aluminum, copper, lead, and zinc) through export of end-of-life vehicles (ELVs) from Japan from 1988 to 2005 using the Trade Statistics of Japan and vehicles composition data. Estimates were also made for engine-related rare metals (manganese, nickel, chromium, and molybdenum) under statistical restrictions. This analysis shows that $45 \%$ of iron, $68 \%$ of aluminum, $27 \%$ of copper, $70 \%$ of lead, $25 \%$ of zinc, and $67 \%$ of rare metals in ELVs in Japan were not recycled and flowed out of the country, mostly in the form of used vehicle and parts. The destinations of these metals were mainly developing countries with rudimentary recycling technology. These results strongly indicate that many metal resources that could be utilized domestically from automobiles in Japan were instead scattered and lost overseas.
\end{abstract}

(Received April 11, 2008; Accepted April 17, 2008)

Keywords: Japan, outflow of resources, end-of-life vehicles, engines, base metals, rare metals

\section{1. は じめ に}

資源の多くを海外に依存する日本において, 製品消費・イ ンフラ建設を通じて国内に蓄積される資源ストック（国内ス トック)は, 潜在的な資源供給源として注目を集めてい る1). 一方, 国内ストックが供給する使用済久製品・廃棄物 が，国内でリサイクル処理されずに国外で中古製品・二次資 源として利用されている現状が報告されている ${ }^{2-6)}$. 国内ス トックからの資源回収可能性を高めることは, わが国の資源 供給の安定性を確保する上で重要な命題である7). 資源回収 可能性の議論の出発点として, 国内ストックから使用済久製 品・廃棄物輸出を通じて, ぞのくらいの量の資源が流出して いるかを把握する必要がある. 同時に, 流出した資源の回収 可能性について検討することも重要である.

そこで本稿は, 資源価值の高い使用済久自動車 (End-ofLife Vehicle: ELV)を取り上げ，その輸出に伴う主要金属の 流出量を推計する. さらに, 各金属の流出先および流出形態 を明らかにすることで, 国外での回収可能性について予備的

\footnotetext{
* Mater. Trans. 48(2007) 2436-2444 に掲載
}

\section{な検討を行う.}

本稿の構成は次のとおりである。 まず対象となる金属とそ の流出の捉え方について定義する (2). 次に, 貿易統計と組 成データを用いた流出量の推計法を説明する(3). 続いて, 資源流出量の推計結果および流出資源の回収可能性の検討結 果を示す $(4,5)$. 最後に得られた成果を整理する $(6)$.

\section{2. 対象金属と流出の捉え方}

推計対象として, ELVを構成するベースメタルの内, 鉄, アルミニウム, 銅, 鉛, 亜鉛を取り上げる.レアメタル に関しては, 統計的な制約から, ELV 中のエンジンを構成 する，マンガン，ニッケル，クロム，モリブデンを対象とす る. 以上の対象金属の流出状況は, ELVのリサイクル処理 状況に大きく依存する. ELVの国内に抢けるリサイクル処 理フローとその輸出状況の関係を Fig. 1 に示す. ELVのリ サイクル処理は, 解体工程での中古部品回収, 破砕工程での 金属回収, シュレッダーダスト (Automobile Shredding Residues: ASR)の再資源化・焼却・埋立処理など, 複数の 工程から成る，そして，各工程に応じて，ELVは「中古車」 「中古部品」「二次資源」といった形状で輸出される．つま 


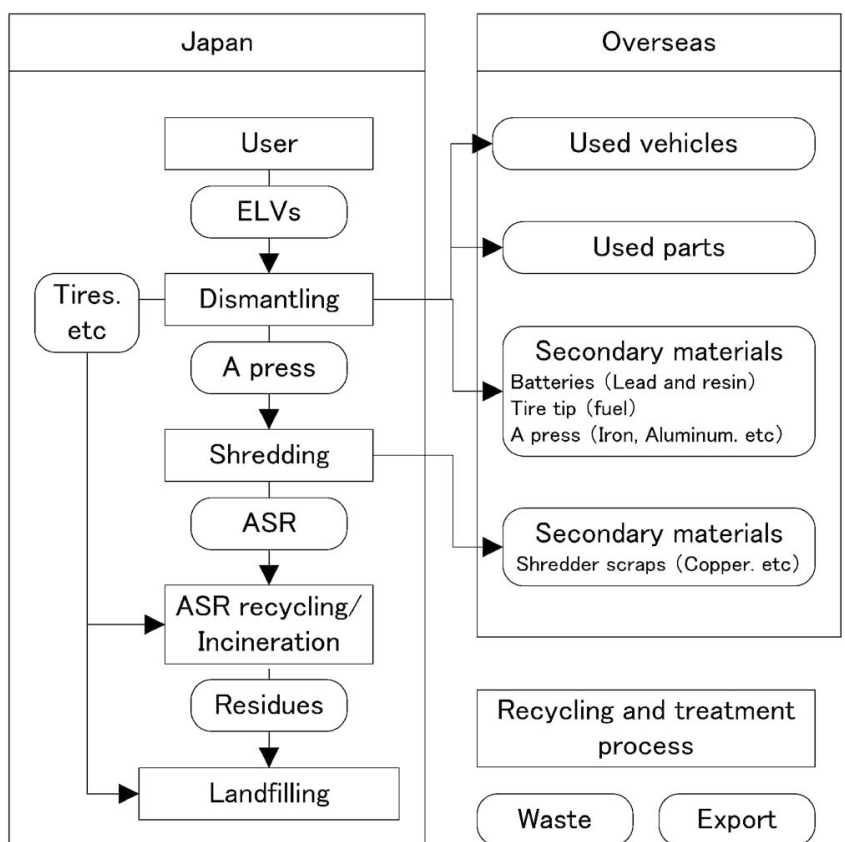

Fig. 1 Recycling flow of ELVs and their export forms.

り，対象金属は，中古車または中古部品内に付随して流出す る，または二次資源の一つとして流出する。本稿では，流出 形態として, 中古車, 中古部品, 二次資源を取り上げる。 ま た，流出先と時点間の傾向を把握するため, 国別流出量を推 計すると共に, 推計期間として, 貿易統計の入手可能な 1988 年から 2005 年の 17 年間を対象とする。ただし, 統計 制約上，取引額が少ない貨物，燃料用のタイヤチップ，ミッ クスメタル(破砕時に発生するハーネス等)は, 推計対象から 除外する.

\section{3. 金属流出量の推計法}

対象期間における対象金属の形態 - 国別流出量は，年 ·形 態 ·国別 $E L V$ 輸出量に, 対応する形態別金属組成を乗じて 推計する. ELV 輸出量の推計法および組成の作成法は 3.1, 3.2 で述べる.

\section{$3.1 \quad E L V$ 輸出量}

$\mathrm{ELV}$ 輸出量は, 基本的に税関が整備する貿易統計 ${ }^{8)}$ を用 いて推計される，貿易統計から，2001 年 4 月以降の中古車 (特殊車を除く) と対象期間中の中古タイヤの輸出量を入手す ることは可能である。しかし，それ以外の ELVに関わる輸 出量については推計する必要がある，推計にあたっては，以

下の貿易統計が有する制約に対応する必要がある。

制約(1): 一部の品目を除いて, 新品と中古品の区別がない.

制約(2) : 輸出品目と輸出先での利用形態が一致しない(例 えば，ELVを切断したハーフカットボディを 「部品」として輸出し，輸出先で結合して「自動 車」として利用している.).

制約(3) : 携帯品の輸出が計上されていない(例えば，ロシ ア船員は組織的に中古車を携帯品として輸出して

\begin{tabular}{|c|c|}
\hline \multicolumn{2}{|c|}{ 1. Sampling of new and used export data } \\
\hline \multicolumn{2}{|c|}{$S Q_{i: 1, j}=\sum_{k 1} A Q_{i:(1+2), j k 1}, \quad S V_{i: 1, j}=\sum_{k 1} A V_{i:(1+2), j k 1}$} \\
\hline$\nabla$ & $\nabla$ \\
\hline $\begin{array}{l}\text { 2. Estimation of new } \\
\text { and used price }\end{array}$ & $\begin{array}{l}\text { 3. Division into new and } \\
\text { used export data }\end{array}$ \\
\hline $\begin{array}{l}P_{i: 1}=\sum_{j}\left(S V_{i: 1, j} / S Q_{i: 1, j}\right) \\
P_{i: 2}=\sum_{j}\left(S V_{i: 2, j} / S Q_{i: 2, j}\right)\end{array}$ & $\rightarrow\left(\begin{array}{l}A Q_{i: 1} \\
A Q_{i: 2}\end{array}\right)=\left(\begin{array}{cc}1 & 1 \\
P_{i: 1} & P_{i: 2}\end{array}\right)^{-1} \cdot\left(\begin{array}{l}A Q_{i:(1+2)} \\
A V_{i:(1+2)}\end{array}\right)$ \\
\hline
\end{tabular}

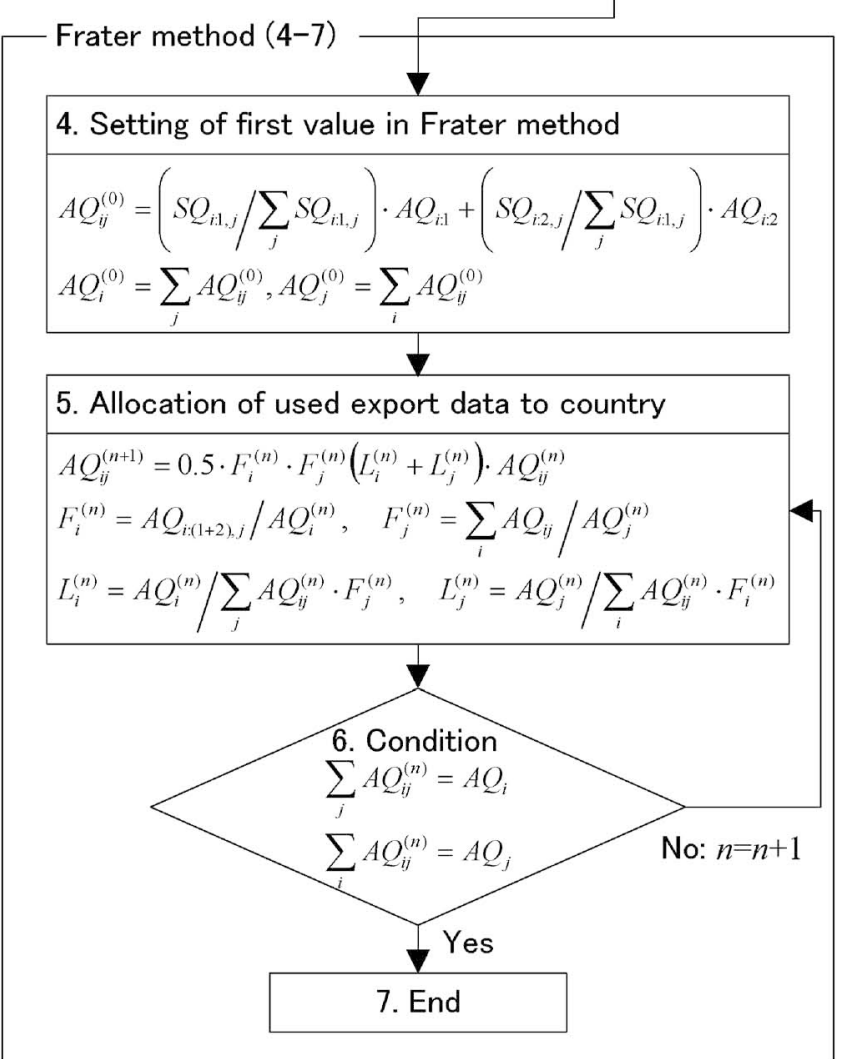

Fig. 2 Calculation flow of the estimation method 1.

いる．ただし， 2005 年 7 月より中古車の携帯輸 出は禁止されている.).

まず，制約(1)に対応するため，貿易統計の税関別輸出デー タ (輸出量，輸出金額)を活用した推計法(1)を開発した．推計 法(1)の計算フローチャートを，Fig. 2 に示す。まず，入手可 能な中古車, 中古タイヤの税関別輸出データから, 新品また は中古品を多く輸出する税関(新品税関, 中古品税関と呼ぶ) を特定化する (Fig. 2 の 1). 次に，新品・中古品の区別がな 
い貿易統計の対象品目について，新品・中古品税関の輸出 データから, 新品・ 中古品価格 (=輸出金額/輸出量) を推計 する(Fig. 2 の 2)．続いて，両価格を用いて，新品と中古品 の結合した輸出量を分割する(Fig. 2 の)。ささらに, 分割し た新品・ 中古品輸出量を周辺分布, 新品 · 中古品税関の輸出 量から得られる国別輸出割合を内部分布として扱い，交通量 の配分計算によく用いられるフレーター法9)を用いて, 中古 品輸出量を国別に配分する(Fig. 2 の 4-7).

次に, 制約(2)への対応法(推計法(2))について説明する. 貿 易統計の提供する品目の内，輸出先での利用形態と一致しな いものを, 既存文献 ${ }^{10,11)}$ および関連業界へのヒアリング調査 より特定化する．そして，特定化した品目の輸出量を貿易統 計から直接抽出する. 特定化した品目が新品・ 中古品の区別 がない場合は，推計法(1)を用いて推計する。

最後の制約(3)への対応として，2005 年 7 月の中古車携帯 輸出の禁止の影響結果を基に推計する(推計法(3)). まず式 (1)より, 携帯輸出禁止による影響台数を推計する. 税関

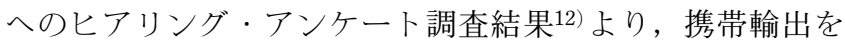
行うロシア船は木材を輸入している知見を得ている. そこ で, 式 (1) から得られる影響台数にロシアからの木材輸入 量を割ることで，木材輸入量あたり携帯輸出台数の原単位を 作成する。この原単位を用いて，対象期間でのロシアへの携 帯輸出台数を推計する.

$$
R B E_{7-12}^{2005}=\sum_{i}\left\{R N E_{7-12, i}^{2005}-\left(R N E_{7-12, i}^{2004} / R N E_{1-6, i}^{2004}\right) \cdot R N E_{1-6, i}^{2005}\right\}
$$

ここで, 式 ( 1 )の添字の $i$ は貿易統計の中古車に関わる品 目 (Table 1 を参照)，2004 と 2005 は年，1-6 7-12 は， 1 月から 6 月までと 7 月から 12 月までの集計, $R B E$ はロシ ア向けの携帯輸出禁止による影響台数, RNE はロシア向け 中古車輸出台数を示す.

以上の 3 推計法と貿易統計の対象品目との対応関係を Table 1 に示す。また，ELV 輸出量の単位は重量で統一す るため, 台数を単位に持つ中古車輸出量は, 筆者が作成した 原単位 ${ }^{12)}$ を用いて重量に変換した。また，タイヤ・バッテ リーの輸出量は, 使用時の交換発生分が含まれているため, 既存文献 ${ }^{13,14)}$ 加得られる交換発生比率を用いて，その分を 控除した。

\section{2 組 成}

今回使用する流出形態別の組成は参考文献12,15-17) 上り作成 される(Table 2)。中古車の組成は，乗用車と貨物車の違い を考慮した．特殊車は，貨物車の組成を代用した．中古部品 の組成では, エンジン系, 足回り系, 電装系, 車体系, タイ ヤの違いを考慮した。二次資源では, バッテリーとAプレ ス $(\mathrm{ELV}$ から部品を回収した後，プレス加工されたもの)の

Table 1 Estimation methods and corresponding items in the Trade Statistics of Japan.

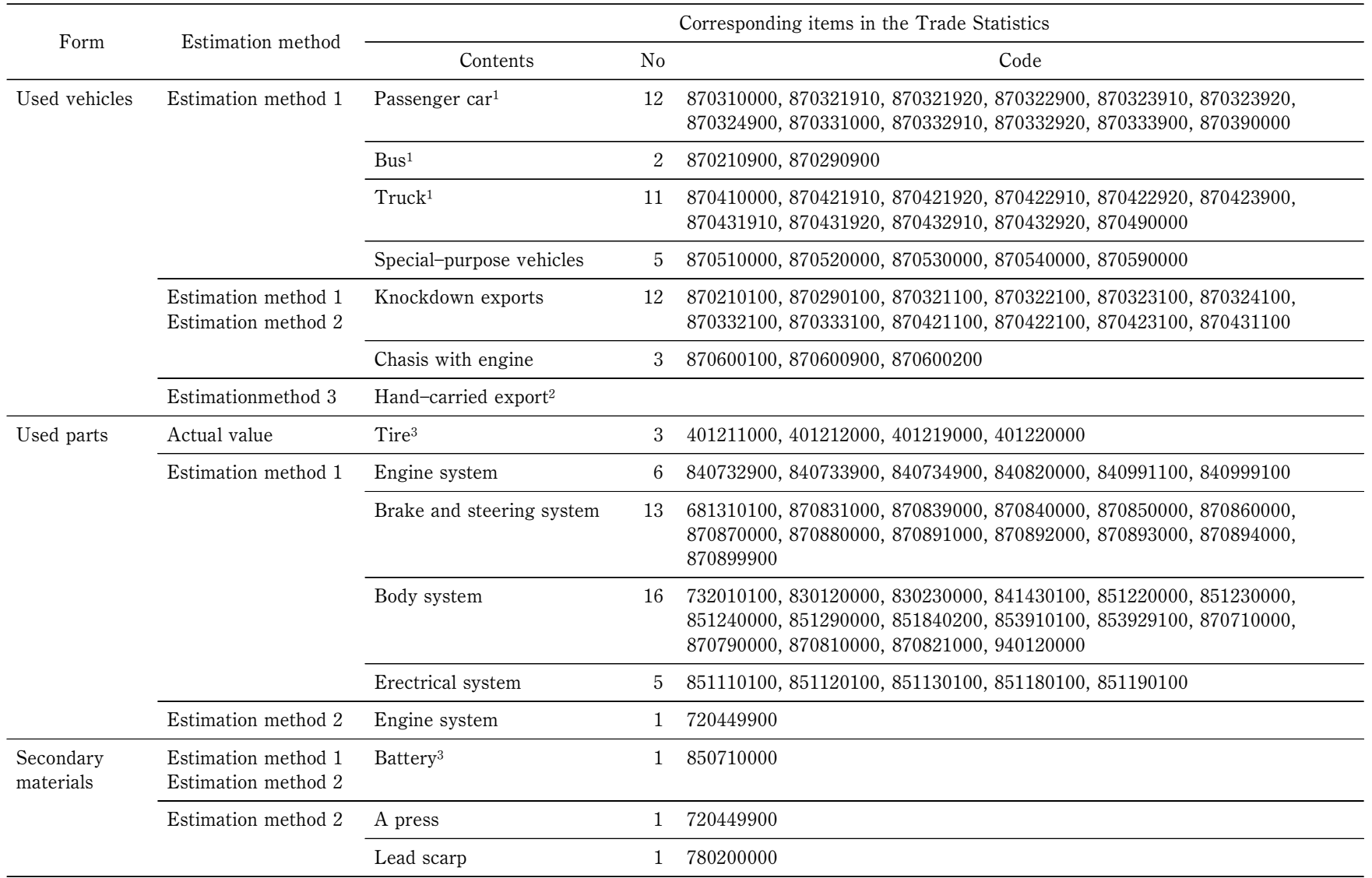

\footnotetext{
1 This paper can obtain actual data for used vehicles from April, 2001 for the change of the item classification in trade statistics.

2 Used vehicles exported by hand-carrying have been accounted in the trade statistics from July, 2005 by the prohibition of hand-carried export.

${ }^{3}$ As the amounts of tires and batteries exported include those that are to be replaced during use, we need to exclude that amount.
} 
組成12)を取り上げた。加えて，製造年による組成の変化に ついても検討した。ここでは，乗用車の製造年別組成デー タ16)を用いて各金属組成の上下限幅を設定した (Table 3). ただし，統計的な制約より，レアメタル，A プレスの組成 の変動は考慮対象から除いた。

\section{4. 金属流出量の推計結果}

資源流出量の推計結果を説明する前に，そのベースとなる ELV 輸出量の推計結果について概観する (Fig. 3). ELV 輸 出量は, 1988 年の 73 万トンから 2005 年の 260 万トンまで と急増している結果が得られた．輸出に占める中古車・中古 部品の割合が極めて高いことが分かる．主要な輸出先を見る
と，中古車はロシア，ニュージーランド，フィリピンなど， 中古部品はアメリカ, インドネシア, マレーシア, 二次資源 は韓国，台湾，中国に多く輸出されている．このことから， 中古車, 中古部品, 二次資源の順に, 近隣国または低所得国 への輸出が増加する傾向が確認できる.

以上の 1988 年から 2005 年での ELV 輸出に伴い国外に流 出した金属量の推計結果を, Table 4 に示す. 対象 17 年間 において，国内で廃棄された自動車のベースメタルのなか で，鉄 19 百万 $\mathrm{t} ，$ アルミニウム 270 万 $\mathrm{t}$ ，銅 23 万 $\mathrm{t}$, 鉛 38 万 $\mathrm{t}$ ，亜鉛 68 千 $\mathrm{t}$ が，国内で回収されずに国外に流出して いる結果が得られた。 エンジン由来のレアメタルでは, マン ガン 22 千 $\mathrm{t}$, ニッケル 43 百 $\mathrm{t}$, クロム 34 千 $\mathrm{t}$, モリブデン 12 百 $\mathrm{t}$ が，国外に流出している結果が得られた。 また，製

Table 2 Composition of base and rare metals (unit : mass\%).

(a) Base metals

(Range)

\begin{tabular}{|c|c|c|c|c|c|c|c|c|}
\hline & & Iron & Aluminum & Copper & Lead & Zinc & Others & Total \\
\hline \multirow[t]{2}{*}{ Used vehicles } & Passenger car & $\begin{array}{c}69 \\
(65-73)\end{array}$ & $\begin{array}{c}6.2 \\
(3.7-8.6)\end{array}$ & $\begin{array}{c}1.5 \\
(1.1-1.9)\end{array}$ & $\begin{array}{c}0.64 \\
(0.49-0.79)\end{array}$ & $\begin{array}{c}0.54 \\
(0.41-0.68)\end{array}$ & 22 & 100 \\
\hline & Truck & $\begin{array}{c}70 \\
(66-74) \\
\end{array}$ & $\begin{array}{c}4.9 \\
(3.0-6.8) \\
\end{array}$ & $\begin{array}{c}0.53 \\
(0.40-0.66) \\
\end{array}$ & $\begin{array}{c}0.71 \\
(0.55-0.87) \\
\end{array}$ & $\begin{array}{c}0.020 \\
(0.015-0.025) \\
\end{array}$ & 24 & 100 \\
\hline \multirow[t]{5}{*}{ Used parts } & Engine system & $\begin{array}{c}73 \\
(63-83)\end{array}$ & $\begin{array}{c}20 \\
(12-28)\end{array}$ & $\begin{array}{c}0.33 \\
(0.25-0.40)\end{array}$ & $\begin{array}{c}0.19 \\
(0.15-0.23)\end{array}$ & $\left(\begin{array}{l}0 \\
-\end{array}\right)$ & 6.1 & 100 \\
\hline & Brake and steering system & $\begin{array}{c}86 \\
(80-91)\end{array}$ & $\begin{array}{c}12 \\
(7.4-17)\end{array}$ & $\left(\begin{array}{l}0 \\
-)\end{array}\right.$ & $\begin{array}{c}0.10 \\
(0.074-0.12)\end{array}$ & $\left(\begin{array}{l}0 \\
-\end{array}\right)$ & 1.9 & 100 \\
\hline & Body system & $\begin{array}{c}74 \\
(67-82)\end{array}$ & $\left(\begin{array}{l}0 \\
-\end{array}\right)$ & $\left(\begin{array}{l}0 \\
-\end{array}\right)$ & $\begin{array}{c}0.017 \\
(0.013-0.020)\end{array}$ & $\begin{array}{c}0.93 \\
(0.70-1.4)\end{array}$ & 25 & 100 \\
\hline & Erectrical system & $\begin{array}{c}24 \\
(11-38)\end{array}$ & $\begin{array}{c}3.9 \\
(3.0-4.8)\end{array}$ & $\begin{array}{c}27 \\
(21-33)\end{array}$ & $\begin{array}{c}0.39 \\
(0.29-0.49)\end{array}$ & $\begin{array}{c}1.2 \\
(1.1-1.3)\end{array}$ & 43 & 100 \\
\hline & Tire & $\begin{array}{c}14 \\
(10-18) \\
\end{array}$ & $\left(\begin{array}{c}0 \\
-\end{array}\right)$ & $\left(\begin{array}{l}0 \\
-\end{array}\right)$ & $\left(\begin{array}{c}0 \\
-\end{array}\right)$ & $\left(\begin{array}{l}0 \\
-\end{array}\right)$ & 86 & 100 \\
\hline \multirow[t]{2}{*}{ Secondary materials } & Battery & $\left(\begin{array}{l}0 \\
-\end{array}\right)$ & $\left(\begin{array}{l}0 \\
-\end{array}\right)$ & $\left(\begin{array}{l}0 \\
-\end{array}\right)$ & $\begin{array}{c}55 \\
(42-68)\end{array}$ & $\left(\begin{array}{l}0 \\
-\end{array}\right)$ & 45 & 100 \\
\hline & A press & $\begin{array}{c}73 \\
(-) \\
\end{array}$ & $\begin{array}{l}4.3 \\
(-) \\
\end{array}$ & $\begin{array}{l}1.5 \\
(-)\end{array}$ & $\begin{array}{l}0.30 \\
(-)\end{array}$ & $\begin{array}{l}0.04 \\
(-)\end{array}$ & 21 & 100 \\
\hline \multicolumn{9}{|l|}{ (b) Rare metals } \\
\hline & & Manganese & Nickel & Chromium & Molybdenum & & Others & Total \\
\hline Engine & & $\begin{array}{l}0.24 \\
(-)\end{array}$ & $\begin{array}{l}0.047 \\
(-)\end{array}$ & $\begin{array}{l}0.38 \\
(-)\end{array}$ & $\begin{array}{l}0.013 \\
(-)\end{array}$ & & 99 & 100 \\
\hline
\end{tabular}

Table 3 Composition by product year and the variation rate.

\begin{tabular}{|c|c|c|c|c|c|c|c|c|}
\hline & \multicolumn{6}{|c|}{ Composition by car product year (unit : mass $\%$ ) : $X$} & \multicolumn{2}{|c|}{ Variation rate ${ }^{1}$} \\
\hline & 1977 & 1980 & 1983 & 1986 & 1989 & 1992 & Upper & Lower \\
\hline Iron Cast iron & 3.2 & 2.8 & 2.2 & 1.7 & 1.7 & 2.1 & 1.3 & 0.69 \\
\hline Cold rolled common steel sheets & 38 & 34 & 29 & 26 & 23 & 15 & 1.4 & 0.57 \\
\hline high tensile strength common steel & 0.5 & 1.4 & 4.1 & 7.3 & 6.4 & 3.9 & 1.9 & 0.13 \\
\hline Galvanized common steel & 4.4 & 7.2 & 7.8 & 8.2 & 13 & 20 & 1.6 & 0.36 \\
\hline Common steel pipes & 2.2 & 2.3 & 2.3 & 2.7 & 2.4 & 2.0 & 1.1 & 0.85 \\
\hline Carbon special steel & 6.8 & 6.1 & 6.0 & 6.1 & 6.0 & 5.8 & 1.1 & 0.92 \\
\hline Alloy special steel & 4.6 & 3.8 & 3.6 & 3.4 & 3.5 & 3.7 & 1.2 & 0.85 \\
\hline Free-cutting special steel & 0.70 & 1.00 & 1.00 & 1.4 & 1.9 & 2.1 & 1.5 & 0.50 \\
\hline Stainless steel & 0.90 & 0.90 & 0.90 & 1.0 & 1.0 & 1.4 & 1.2 & 0.78 \\
\hline Spring special steel & 2.0 & 1.5 & 1.5 & 1.5 & 1.4 & 1.3 & 1.2 & 0.79 \\
\hline Other special steel & 1.1 & 1.4 & 1.3 & 1.6 & 1.3 & 1.0 & 1.2 & 0.77 \\
\hline Aluminum & 2.6 & 3.3 & 3.5 & 3.9 & 4.9 & 6.0 & 1.4 & 0.60 \\
\hline Copper & 0.90 & 0.80 & 0.90 & 1.00 & 1.30 & 1.00 & 1.2 & 0.76 \\
\hline Zinc & 0.50 & 0.30 & 0.40 & 0.40 & 0.40 & 0.30 & 1.3 & 0.75 \\
\hline Non metals & 15 & 17 & 19 & 20 & 19 & 20 & & \\
\hline Total & 100 & 100 & 100 & 100 & 100 & 100 & & \\
\hline
\end{tabular}

1 Upper variation rate $=X_{\text {upper }} /\left\{\left(X_{\text {upper }}+X_{\text {lower }}\right) / 2\right\}$, Lower variation rate $=X_{\text {lower }} /\left\{\left(X_{\text {upper }}+X_{\text {lower }}\right) / 2\right\}$ 


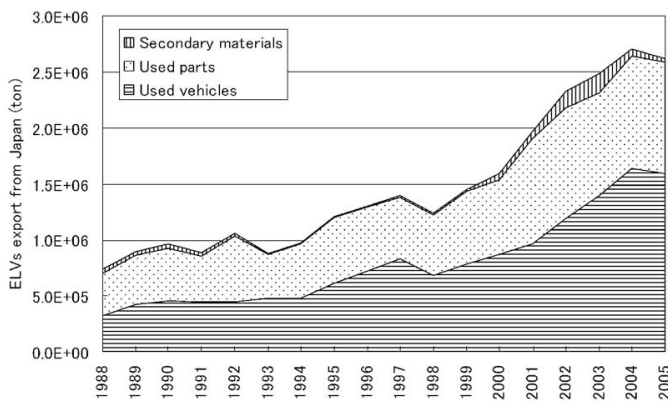

(a) ELVs export from Japan

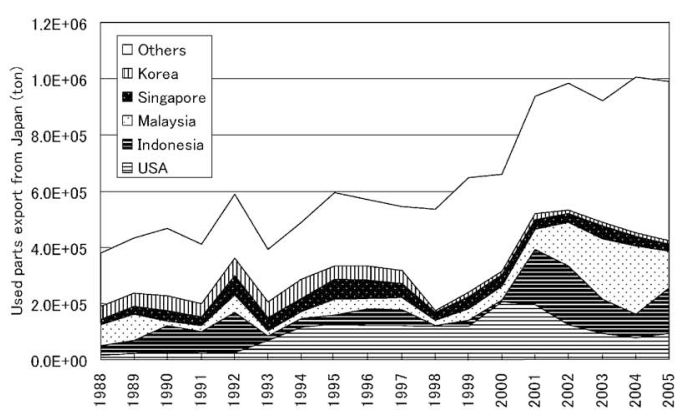

(c) Used parts export from Japan

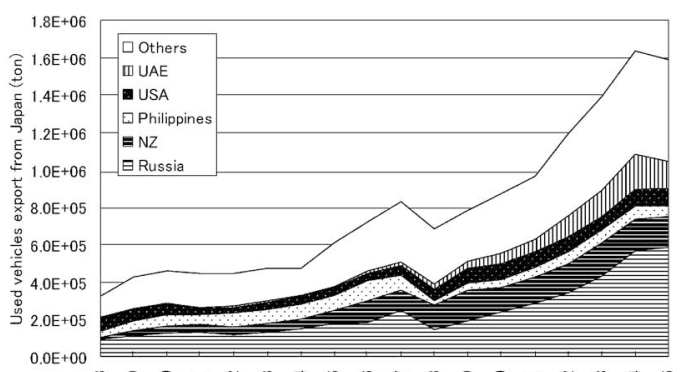

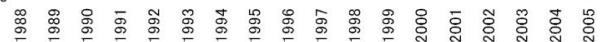

(b) Used vehicles export from Japan

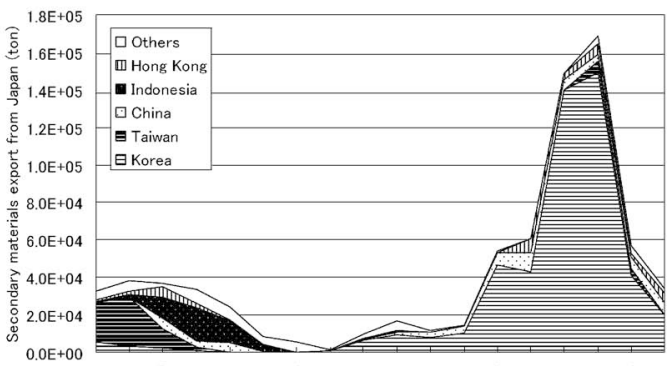

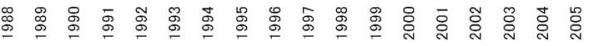

(d) Secondary materials export from Japan

Fig. 3 Export amounts of ELVs from Japan.

Table 4 Total outflow amounts of metals from ELVs between 1988 and 2005.

\begin{tabular}{lc}
\hline & Resources outflow (ton) \\
\hline Base metals in ELVs & \\
Iron & $(1.9 \pm 0.2) \times 10^{7}$ \\
Aluminum & $(2.7 \pm 1.0) \times 10^{6}$ \\
Copper & $(2.3 \pm 0.5) \times 10^{5}$ \\
Lead & $(3.8 \pm 0.3) \times 10^{5}$ \\
Zinc & \\
\hline Rare metals in engins & $2.8 \pm 1.7) \times 10^{4}$ \\
Manganese & $2.2 \times 10^{4}$ \\
Nickel & $4.3 \times 10^{3}$ \\
Chromium & $3.4 \times 10^{4}$ \\
Molybdenum & $1.2 \times 10^{3}$ \\
\hline
\end{tabular}

造年による組成变化がベースメタルの推計結果に与える影響 を見ると，鉄，鉛の变動幅は $\pm 10 \%$ 以内に収まるものの， 他の金属は $\pm 20 \%$ を超える結果となった．特に，アルミニ ウムの変動幅は $\pm 40 \%$ 近くの值となり, 製造年による組成 変化の影響を強く受けることが分かる.

続いて, 2005 年に着目して, 金属流出量の推計結果と, 対応する金属の国内発生量および二次資源としての輸出量と の比較結果を, Table 5 に示す. 2005 年においては, 鉄 190 万 $\mathrm{t}$ ，アルミニウム 25 万 $\mathrm{t}$, 銅 24 千 $\mathrm{t}$, 鉛 27 千 t, 亜鉛 80 百 $\mathrm{t}$, マンガン 20 百 $\mathrm{t}$, ニッケル $390 \mathrm{t}$, クロム 32 百 $\mathrm{t}$, モ リブデン $110 \mathrm{t}$ 流出している結果が得られた. これらの流出 量は, 自動車廃棄に伴い国内で発生した各金属の内, 鉄 $45 \%$ ，アルミニウム $68 \%$, 銅 $27 \%$, 鉛 $70 \%$, 亜鉛 $25 \%$, レアメタル $67 \%$ の割合を占めている. 二次資源として直接 的に輸出した量と比較すると, アルミニウム, 鉛, 亜鉛, ク ロム, マンガンの流出量は, 2.1 倍から 6.5 倍の值となり, 国全体から見ても無視できない量であることが言える.
Table 5 Comparison of resources outflow with corresponding generation and direct export in 2005 .

\begin{tabular}{|c|c|c|c|c|c|}
\hline & $\begin{array}{l}\text { Resources out- } \\
\text { flow (ton) : }\end{array}$ & $\begin{array}{l}\text { Generation } \\
\text { (ton) }: \mathrm{B}\end{array}$ & $\begin{array}{l}\text { Direct export } \\
\text { (ton) : C }\end{array}$ & $\mathrm{A} / \mathrm{B}$ & $\mathrm{A} / \mathrm{C}$ \\
\hline \multicolumn{6}{|c|}{ Base metals in ELVs } \\
\hline Iron & $1.9 \times 10^{6}$ & $4.1 \times 10^{6}$ & $5.3 \times 10^{6}$ & 0.45 & 0.35 \\
\hline Aluminum & $2.5 \times 10^{5}$ & $3.7 \times 10^{5}$ & $9.6 \times 10^{4}$ & 0.68 & 2.6 \\
\hline Copper & $2.4 \times 10^{4}$ & $8.9 \times 10^{4}$ & $4.2 \times 10^{5}$ & 0.27 & 0.057 \\
\hline Lead & $2.7 \times 10^{4}$ & $3.8 \times 10^{4}$ & $8.9 \times 10^{3}$ & 0.70 & 3.0 \\
\hline Zinc & $8.0 \times 10^{3}$ & $3.2 \times 10^{4}$ & $3.9 \times 10^{3}$ & 0.25 & 2.1 \\
\hline \multicolumn{6}{|c|}{ Rare metals in engins } \\
\hline Manganese & $2.0 \times 10^{3}$ & $3.0 \times 10^{3}$ & $1.0 \times 10^{3}$ & 0.67 & 1.9 \\
\hline Nickel & $3.9 \times 10^{2}$ & $5.9 \times 10^{2}$ & $1.1 \times 10^{3}$ & 0.67 & 0.35 \\
\hline Chromium & $3.2 \times 10^{3}$ & $4.7 \times 10^{3}$ & $4.9 \times 10^{2}$ & 0.67 & 6.5 \\
\hline Molybdenum & $1.1 \times 10^{2}$ & $1.6 \times 10^{2}$ & $9.0 \times 10$ & 0.67 & 1.2 \\
\hline
\end{tabular}

\section{5. 流出金属の回収可能性の検討結果}

4 の結果は, 国内ストックから供給される ELV 中の有用 金属の多くは国内で回収されずに国外に流出していることを 意味している.ここでは, 国外に流出した金属の回収可能性 について, 流出先および流出形態に着目して検討する.

まず，Fig. 4 に，対象期間に打ける対象金属の流出先での 蓄積量と, 日本から流出先までの距離 ${ }^{18)}$ と流出先の一人あ たり GDP (2005 年の值を使用) ${ }^{19)}$ の関係を図示する．このと き，流出先までの距離は回収コスト，一人あたり GDP は回 收技術水準の代理指標として用いている.ただし，エンジン 由来に限定されるレアメタルは，金属間での傾向と同様にな るため, 合計した結果を示す.この図の見方として, 流出先 までの距離が短く(回収コストの低い)，一人あたり GDP が 高い(流出先の技術水準が高い20,21) 場所に蓄積量が多く分布 する場合，その金属の国外での回收可能性が高いと判断す 


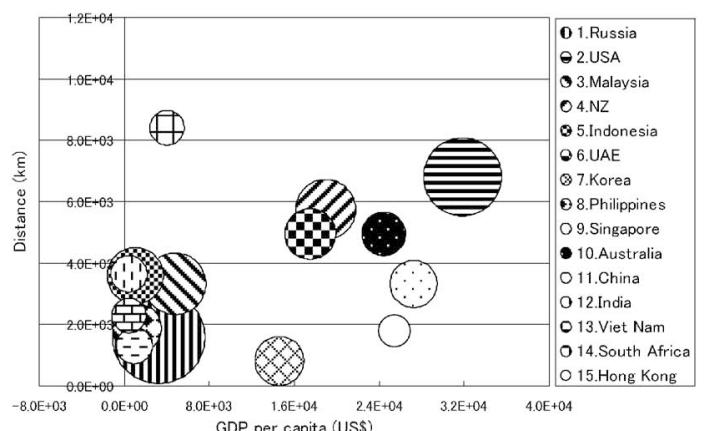

(a) Iron

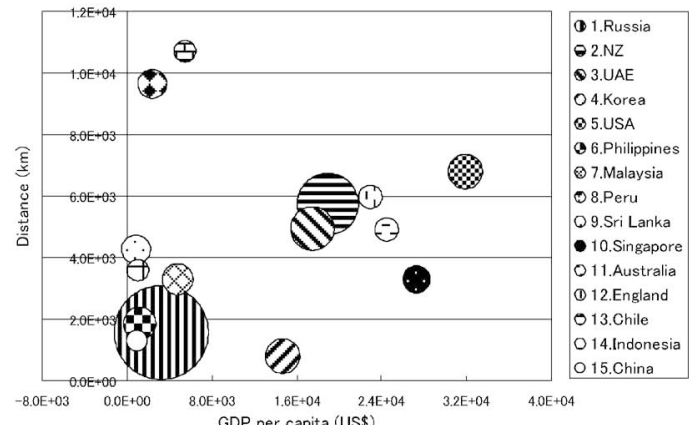

(c) Copper

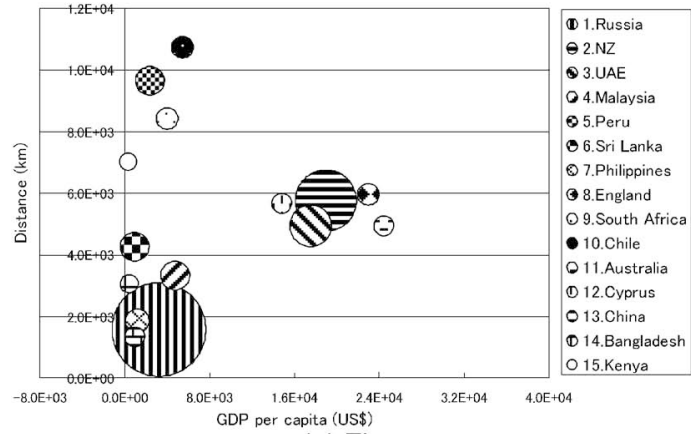

(e) Zinc

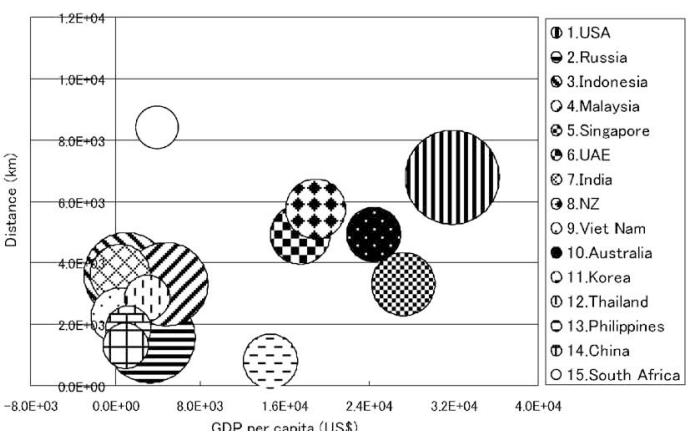

(b) Aluminum

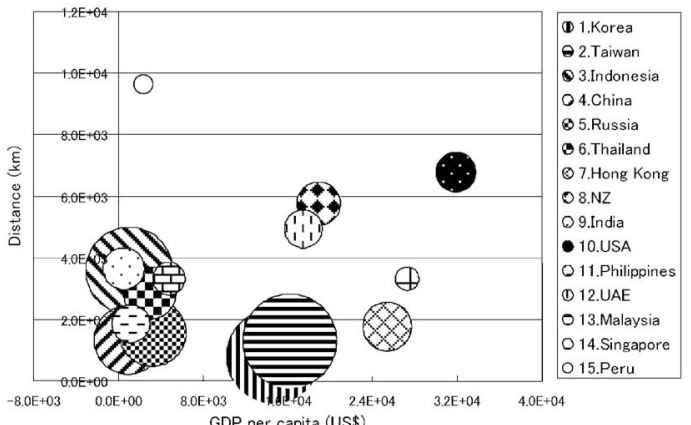

(d) Lead

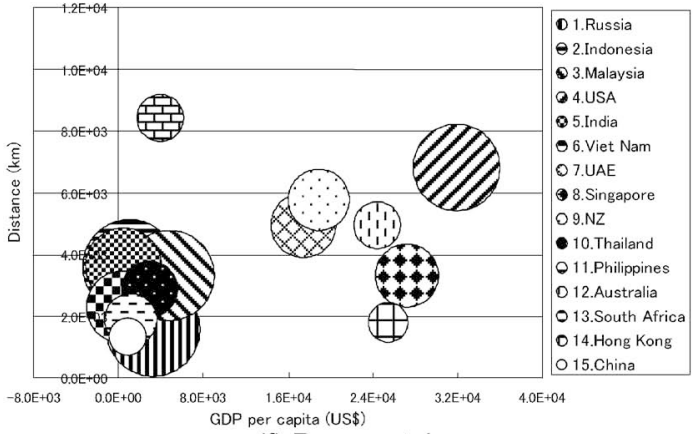

(f) Rare metals

Fig. 4 Relationship between the outflow amounts of metals from Japan by the destination, distance, and GDP per capita.

る. 反対の場合は，資源拡散リスクが高いことになる.

以上の判断基準に基づいて図を解釈すると，まず，アルミ ニウム，レアメタルの回収可能性が他の金属と比較して高い と言える，続いて，鉄，鉛，銅，亜鉛の順で回収可能性が落 ちていく(または資源拡散リスクが高くなる)傾向がある。た だし, 回収可能性が相対的に高いアルミニウム, レアメタル に関しても，日本からの距離が 3 千 $\mathrm{km}$ 以上，かつ一人あた りGDP が 1 万ドル未満の国が占める割合は $60 \%$ を超えて いる.このことから, 自動車に関しては, 国内ストック中の 有用金属の資源拡散リスクが高い状況にあると言える.

続いて, Fig. 5 に, 流出形態に着目した金属流出量の時系 列傾向を示す. Fig. 5 と同様に, レアメタルは合計した結果 を示す。

結果として, 亜鉛, 銅, 鉄, アルミニウム, レアメタルの 順で, 中古車としての形態での流出量は減少し, 反対に中古 部品としての流出量が増加している傾向が確認された. 以上 の金属は，二次資源の形態で流出することは少なく，また流 出量は年々増加する傾向にある. 一方, 鉛は他の金属と異な り，二次資源としての形態での流出割合が大きく，また，そ の時系列傾向も年によって大きく変動する傾向を得た. 中古
車 · 中古部品の形態で流出する金属の回収は, 中古車 · 部品 が廃棄されるまで待つことになる.よって, それらの金属 は, 回収まである程度のタイムラグが生じる. また, 中古 車. 中古部品輸出量は, 流出先での自動車需要に依存する. よって現在の国際的なモータリゼーションの進展を勘案する と, 今後も中古車・中古部品を通じた金属流出量は増加する ことが予想される.

以上より, Fig. 4 で得られた現状での資源拡散リスクが高 い状況も踏まえると, 早急に流出金属への対策を講じること で，国内ストックの資源回収可能性を効果的に高めることが 可能であると言える. このとき, 日本から近距離かつ回収技 術を持たない国には国際的な回収システムの構築, また遠距 離かつ回収技術を持たない国には日本からの技術移転など, 流出先の状況に応じた対策が求められる.

\section{6. おわりに}

国内ストックからの資源の回収可能性を議論するにあたっ ては，使用済久製品・廃棄物の輸出に付随して国外に流出す る資源量を把握することが不可欠である，そこで本稿は，資 


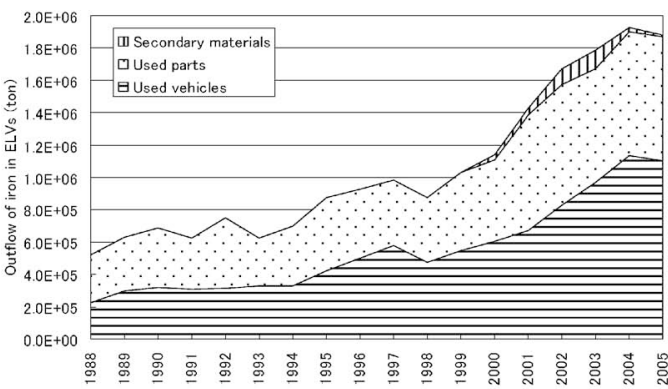

(a) Iron

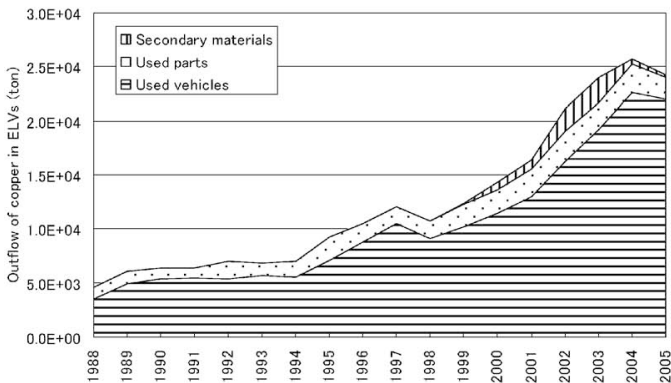

(c) Copper

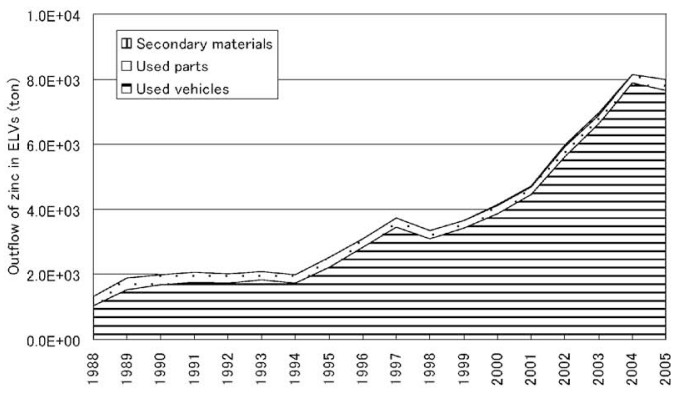

(e) Zinc

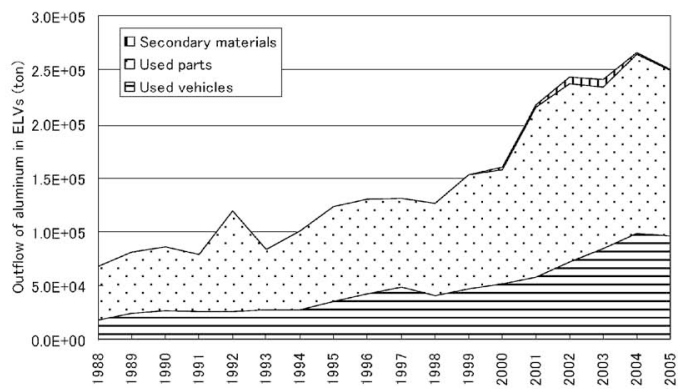

(b) Aluminum

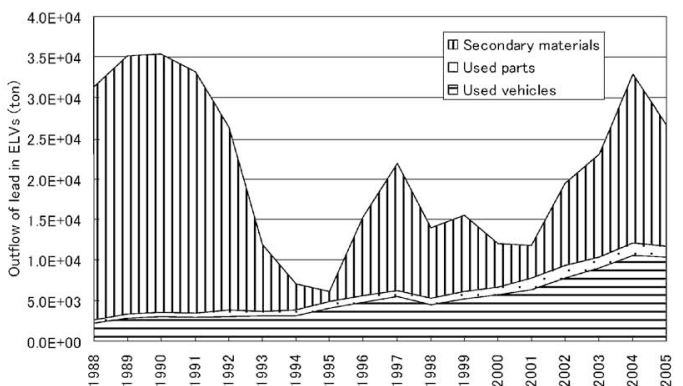

(d) Lead

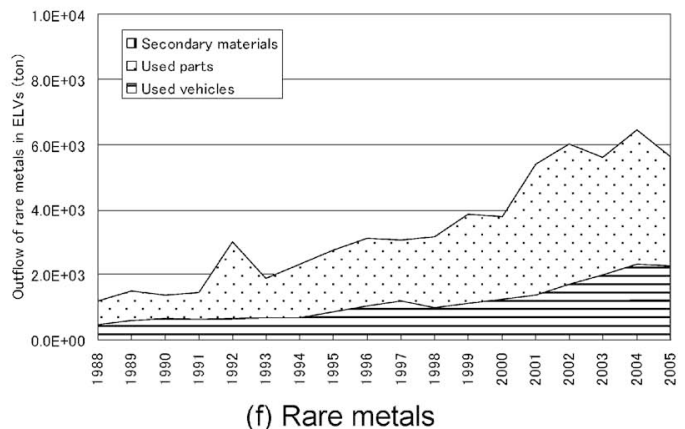

Fig. 5 Outflow amounts of metals from Japan by the export form.

源価值の高い ELV を取り上げ，その輸出に伴うべースメタ ル (鉄, アルミニウム, 銅, 鉛, 亜鉛), レアメタル $($ アンガ ン, ニッケル, クロム, モリブデン)の流出量を推計した. さらに，各金属の流出形態および流出先を明らかにすること で，国外での回収可能性について予備的な検討を行った.

その結果， 1988 年から 2005 年の 17 年間での $\mathrm{ELV}$ 輸出 の急増に伴い，22 百万 $\mathrm{t}$ を超える大量の金属が国外に流出 していること， 2005 年では自動車廃棄に伴い発生した鉄, アルミニウム，鉛，レアメタルの $45 \%$ から $68 \%$ は国外に流 出していることを明らかにした。 また，アルミニウム，鉛， 亜鉛, クロム，マンガンの流出量は，対応する金属の二次資 源輸出量の 2.1 倍から 6.5 倍となり，無視できない量である ことを確認した。さらに，国外に流出した金属の多くは，日 本から遠距離かつ適切な回収技術を持たない低所得国に蓄積 しているため，資源拡散リスクが高いことを示した。同時 に，鉛を除く金属が中古車・中古部品の形態で流出している ため，その回収に向けた対策を講じる時間的猶予があること も把握した。

本稿は, 環境省廃棄物処理等科学研究費補助金「物質ス卜 ック勘定体系の構築とその適用による廃棄物・資源管理戦略
研究 (K1930)」の成果の一部をまとめたものである. 本研究 の推進に際して, George Mason University の Danilo Pelletiere 博士には, 貴重かつ有益な情報 · 意見の提供や参 考資料の紹介等において多大なご協力をいただきました。こ こに感謝の意を表します。

文献

1) National Institute for Materials Science: NIMS Press release (Jan. 20, 2008).

2) S. K. Clerides: Discussion Paper 4859 (Centre for Economic Policy Research, London, 2005).

3) D. Pelletiere and K. A. Reinert: J. Asian. Econn. 20 (2006) 161171.

4) A. Terazono, A. Yoshida, J. Yang, Y. Moriguchi and S. Sakai: J. Mater. Cycles. Waste Manag. 6(2004) 82-96.

5) A. Yoshida, A. Terazono, T. Aramaki and K. Hanaki: J. Mater. Cycles. Waste Manag. 7 (2005) 8-15.

6) M. Fuse and S. Kashima: J. Waste Manag. Exp. 18 (2007) 305313.

7) Ministry of Economy, Trade and Industry: Report of Natural Resource Strategy Study Group (2006).

8) Ministry of Finance: Trade Statistics of Japan http://www.customs.go.jp/toukei/info/index e.ht

9) T. Sasaki and K. Iida: Transport Engineering, Ohmsha (in Japanese) (1992).

10) S. Hayashi: Japanese iron recycling in a turning point, Japan 
Technical Information Services Corporation (in Japanese) (2001).

11) M. Sato and Y. Muramatu: Recycling business, Nihon Hyouron Sha (in Japanese) (2000).

12) M. Fuse: Doctoral Thesis of Chuo University (2005).

13) THE Japan Automobile Tire Manufacturers Association: tire yearbook (2006).

14) Y. Hirai and S. Sakai: J. Waste Manag. Exp. 17 (2006) 404-415.

15) LCA inventory database of Japan Automobile Manufacturers Association, Inc. (2003).

16) Japan Automobile Manufactures Association, Inc. The Motor
Industry of Japan (2002).

17) Special Steel Association of JAPAN, Special Steel Fact-finding Result Report with the Technical Change of Vehicles (in Japanese) (2002) 24-117.

18) This paper use the distance data obtained from Dr. Danilo Pelletiere in Ref. 3).

19) The World Bank, World Development Indicator (2006).

20) N. D. Quang, E. Yamasue, H. Okumura and K. N. Ishihara: Pro. SEE2006 (2006) 998-1001.

21) M. Streucher-Porte, H. Bader, R. Scheidegger and S. Kytzia: Clean. Techn. Environ. Policy. 9(2007) 325-345. 